\title{
FORMULAS FOR FAILURE? WERE THE DOHA TARIFF FORMULAS TOO AMBITIOUS FOR SUCCESS?
}

David Laborde and Will Martin

$\mathrm{D}$

etermining the size of tariff reductions to be undertaken on particular tariff lines is central in any tariff negotiation. ${ }^{1}$ One approach to doing this is the "request and offer" principle that was used in General Agreement on Tariffs and Trade (GATT) negotiations prior to the Kennedy Round. ${ }^{2}$ This has the enormous advantage of allowing countries to choose the products they liberalize and the extent to which they liberalize trade in them. Unfortunately, as demonstrated by Baldwin and Lage (1971) and Baldwin (1986), it is likely to be unsuccessful in obtaining many agreements on tariff reductions that would ex post be regarded as improvements over the status quo. This problem arises because the benefit to the demandeur of any tariff cut by its partner is diluted by the subsequent extension of access on a nondiscriminatory basis. This view was consistent with the outcome of the first five GATT negotiations which, after initially encouraging progress in the first Geneva Round, yielded only small reductions in applied tariffs.

The approach adopted in the Kennedy and Tokyo Rounds, and attempted in the Doha Development Agenda, was to specify a formula for tariff reductions for each member. In principle, this overcomes the free-rider problem involved with bilateral negotiations. Every member can see what is on offer and can take this into account in its evaluation of the proposal. There are many possible formula approaches available for use in trade negotiations (Francois and Martin 2003), but there is neither clarity about the objectives of the negotiators nor any obvious link between the formula chosen and the objectives of negotiators. While we have some broad guidance from economic theory about the approaches to reform that are likely to yield Pareto improvements in economic welfare, we have essentially no guidance on what will

1 This chapter was originally published as Laborde and Martin (2015).

2 The Kennedy Round was the sixth round of negotiations under the GATT era from 1964 to 1967. 
generate the greatest political resistance. Key questions include whether negotiators are seeking to increase the efficiency of their economies subject to the limited political capital provided by market access gains, or whether they seek to offer just enough expansion in market access to bring about an agreement, while minimizing the political costs at home in achieving this outcome.

The Doha Agenda approach ultimately involved formulas that make deeper cuts in the higher tariffs. This is particularly the case in nonagricultural market access (NAMA), where the famous "Swiss formula" used in the Tokyo Round is proposed for tariff cutting. In agriculture, the formula used is a less-aggressive compromise - the "tiered formula" - which places tariffs in tiers, with progressively higher reductions in higher tariffs. These approaches are highly desirable from an economic point of view because higher tariffs generate much higher efficiency costs in the imposing country than do lower tariffs. A key problem with the formula approach, however, is that some tariffs-protected by particularly strong interest groups-are likely to need to be exempted from the general formula treatment for political reasons. In the Kennedy and Tokyo Rounds members sought to keep the number of exceptions to a minimum. This proved an insufficiently rigorous constraint, with the addition of exceptions threatening to spiral, putting the goal of liberalization at risk. In the Doha Agenda negotiators tried a different approach, by specifying constraints on the range of products that could be exempted from the formula treatment, while leaving the specific products to be given lessthan-formula cuts to the discretion of each country's policy makers.

Although this was an important new approach to trade reform, it encountered several difficulties that may have contributed to the travails of the negotiations. The first was that the formulas chosen were particularly progressive in their application-cutting the highest tariffs by the largest percentage. This appears to have contributed to pressure for what we see as a particularly comprehensive and complex set of exceptions. This pressure for exceptions, and the poorly defined nature of some of the exception rules, resulted in the loss of the transparency about benefits that is meant to be one of the key advantages of a formula-based negotiation over one based on request and offer procedures. When the negotiations collapsed in 2008, the chief negotiator for the United States-the most experienced country in the negotiations and perhaps the one with access to the greatest analytical capacity-expressed concern that the draft agreement was a "Black Box" in terms of its impacts on market access (see Schwab 2011).

Given this lack of transparency, analysis of the proposals offered in the negotiations required very careful analysis of the likely ways in which 
countries would choose to use the numerous flexibilities available to them (see, for example, Jean, Laborde, Martin 2011) and careful use of aggregation (Laborde, Martin, and van der Mensbrugghe 2011) to allow for the sharp changes in tariff profiles resulting from the use of the formulas and exceptions. Only with this analysis did it become clear that the proposed agreements, despite their flaws, offered substantial improvements in market access and economic welfare (Martin and Mattoo 2011). The political costs of reform are particularly important in the context of the Doha Agenda, because of the difficult landscape on which the Doha Round is taking place, with low tariffs on the industrial product tariffs that have provided the traditional fuel for negotiations (Martin and Messerlin 2007). Bouët and Laborde (2010) explored this background using a game-theoretic approach and found that given the heterogeneity of WTO members, careful design of formulas and flexibilities would be needed to achieve an outcome that was welfare-improving for all countries.

In this chapter we outline the nature of the tariff-cutting rules and exceptions under consideration in the Doha Round and their implications for market access. Because they are very different in their details, we outline the agricultural proposals first and then those for nonagricultural market access. We focus on the December 2008 proposals that were under discussion when the negotiations collapsed and have not subsequently been modified, although negotiators could choose an alternative starting point if the negotiations were renegotiated. We consider the political costs of securing agreement under proportional tariff cuts and the key tariff-cutting approaches in the latest Doha proposals.

\section{The Agricultural Formula Proposals}

Agricultural markets remain highly distorted by border measures in both developed and developing countries. A central feature of the draft agreement for agriculture is a tiered formula for cutting agricultural tariffs, which provides for larger proportional cuts on higher-and hence more economically costly-tariff rates. The Modalities (WTO 2008a) involve four bands, with the boundaries for developed and developing countries given in Table 4.1, together with the proportional cuts to be made in bound agricultural tariffs in each band. The cuts for developing countries are two-thirds of those for developed countries because of the long-standing view in the WTO that special and differential treatment for developing countries implies smaller tariff cuts than for the industrial countries. The bands for developing countries are 
TABLE 4.1 The tiered formula for cuts in agricultural tariff bindings

\begin{tabular}{llllll}
\hline & \multicolumn{2}{c}{ Developed } & & \multicolumn{2}{c}{ Developing } \\
\cline { 2 - 3 } \cline { 5 - 6 } Band & Range $(\%)$ & Cut $(\%)$ & & Range $(\%)$ & Cut (\%) \\
\hline$A$ & $\mathrm{t}_{0} \leq 20$ & 50 & & $\mathrm{t}_{0} \leq 30$ & 33.3 \\
B & $20<\mathrm{t}_{0} \leq 50$ & 57 & & $30<\mathrm{t}_{0} \leq 80$ & 38 \\
$\mathrm{C}$ & $50<\mathrm{t}_{0} \leq 75$ & 64 & & $80<\mathrm{t}_{0} \leq 130$ & 42.7 \\
D & $\mathrm{t}_{0}>75$ & 70 & & $\mathrm{t}_{0}>130$ & 46.7 \\
Average cut & Min & 54 & & Max & 36 \\
\hline
\end{tabular}

Source: Authors' summary based on WTO (2008a).

wider partly for this reason, and partly because the higher average tariffs in developing countries means they might otherwise face higher average cuts in their tariffs than the industrial countries.

Unlike the Swiss formula used in the nonagricultural market access negotiations, this formula does not provide a smooth mapping from initial to final tariffs. The larger cuts applying to tariffs in the higher bands mean that tariffs just above the boundaries between the bands end up somewhat lower than some tariffs in the lower bands, resulting in the surprising saw-tooth tariff mapping depicted in Figure 4.1.

To address the interests of particular groups of countries, the modalities also include a wide range of special features, such as deeper cuts on tropical and tariff-escalation products, and flexibilities that allow countries to make smaller cuts on "sensitive" products and zero cuts on "special" products. ${ }^{3}$ Some groups of countries, such as recently acceded countries, are also able to make smaller or zero cuts in their agricultural tariffs. The details of these exceptions, and the approaches used to model their impacts, are summarized in Table 4.2 and discussed in Laborde and Martin (2011a). Another important factor also discussed in Laborde and Martin (2011a) is the impact of the many gaps between bound and applied tariff rates: The formula is applied to bound tariffs, so how the formula ultimately affects applied tariffs is a complicated issue.

3 In addition, for products covered by tariff-rate quotas (TRQ), flexibilities will be mitigated by an increase of existing quotas. It is noteworthy to underline that beyond the tariffs and the size of the quota, the administration method of TRQ $s$ is critical to measure the final market access delivered by this instrument, and the 2013 Bali Package (see WT/L/914) ensures effective market access. 
FIGURE 4.1 The pattern of tariff cuts under the tiered formula

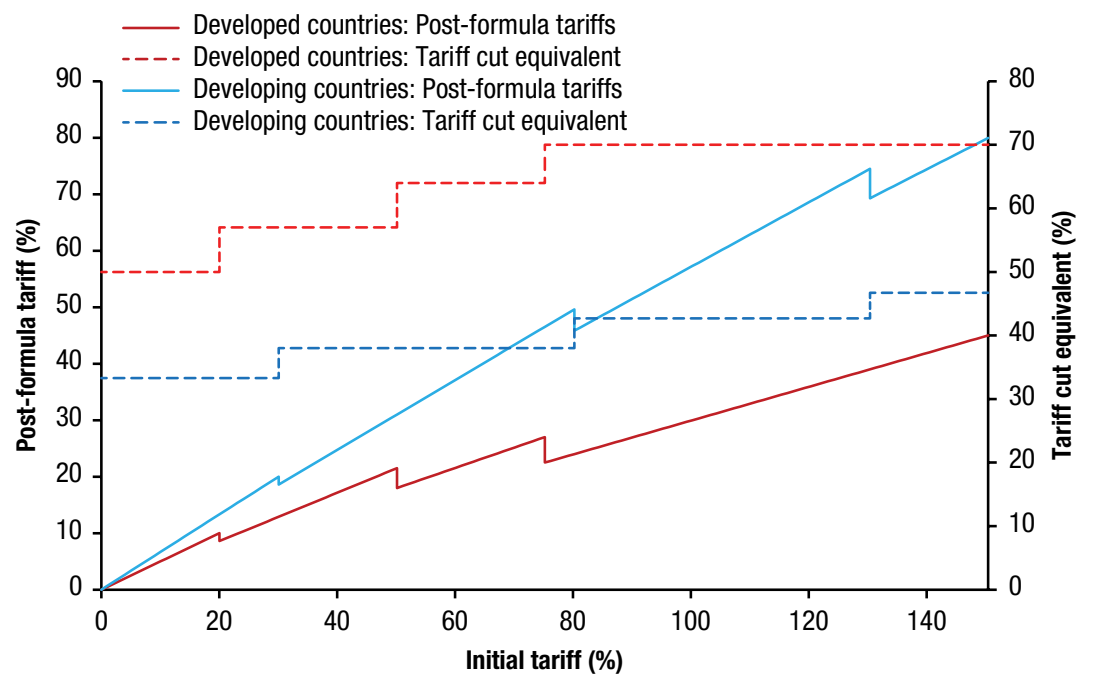

Source: Authors' summary based on WTO (2008a).

The scenarios for which we provide results are:

- Baseline: Tariffs that would apply in the absence of a DDA agreement in 2025. These estimates are based on 2004 tariffs, with adjustments for internationally binding commitments to reform.

- B: Tariffs following implementation of the DDA formula without flexibilities.

- C: Tariffs following implementation of the formula with country exceptions, such as those for least developed countries (LDCs), small and vulnerable economies (SVEs), and recently acceded members (RAMs).

- D: Tariffs after the tariff-cutting formulas with flexibilities for countries and products.

In Table 4.3, we see that the formulas applied without exceptions (scenario B) would result in a decline from 14.6 to 9 percent in average applied agricultural tariffs worldwide. In the WTO developed countries, the result is a cut of more than 50 percent in applied rates, from 15.4 to 7.0 percent. In WTO developing countries other than the LDCs, the reduction is from 13.7 percent to 11.2 percent, a cut that is smaller than in the industrial countries partly 
TABLE 4.2 Key elements of the agricultural tariff cuts used in the analysis for agriculture

\begin{tabular}{|c|c|c|c|c|c|c|}
\hline $\begin{array}{l}\text { Element of } \\
\text { negotiation }\end{array}$ & $\begin{array}{l}\text { Developed } \\
\text { Countries }\end{array}$ & $\begin{array}{l}\text { Developing } \\
\text { Countries }\end{array}$ & $\begin{array}{l}\text { Least } \\
\text { Developed } \\
\text { Countries } \\
\text { (LDCs) }\end{array}$ & $\begin{array}{l}\text { Small and } \\
\text { Vulnerable } \\
\text { Economies } \\
\text { (SVEs) }\end{array}$ & $\begin{array}{l}\text { Very } \\
\text { Recently } \\
\text { Acceded } \\
\text { Members } \\
\text { (VRAMs) }\end{array}$ & $\begin{array}{l}\text { Recently } \\
\text { Acceded } \\
\text { Members } \\
\text { (RAMs) }\end{array}$ \\
\hline Bands & 0/20/50/75 & 0/30/80/130 & $\begin{array}{l}\text { no liberal- } \\
\text { ization }\end{array}$ & $\begin{array}{l}\text { as developing } \\
\text { countries }\end{array}$ & $\begin{array}{l}\text { no liberal- } \\
\text { ization }\end{array}$ & \\
\hline \multirow[t]{2}{*}{$\begin{array}{l}\text { Proportional } \\
\text { cut }\end{array}$} & $50 / 57 / 64 / 70$ & $33.3 / 38 / 42.7 / 46.7$ & $\begin{array}{l}\text { no liberal- } \\
\text { ization }\end{array}$ & $\begin{array}{l}\text { Developing } \\
\text { countries' cut } \\
\text { reduced by } 10 \\
\text { points. }\end{array}$ & $\begin{array}{l}\text { no liberal- } \\
\text { ization }\end{array}$ & $\begin{array}{l}\text { developing } \\
\text { countries' } \\
\text { cut reduced } \\
\text { by } 8 \text { points }\end{array}$ \\
\hline & \multicolumn{2}{|c|}{$\begin{array}{l}\text { Scaled proportionately if the average } \\
\text { cut (including sensitive, tropical, and } \\
\text { tariff escalation products) }<54 \% \\
\text { in industrial countries; if }>36 \% \text { in } \\
\text { developing countries }\end{array}$} & & & & \\
\hline \multirow[t]{2}{*}{$\begin{array}{l}\text { Sensitive } \\
\text { products }\end{array}$} & $5 \%$ of lines & $6.7 \%$ of lines & $\begin{array}{l}\text { no liberal- } \\
\text { ization }\end{array}$ & $\begin{array}{l}\text { as developing } \\
\text { countries with } \\
\text { cut reduced } \\
\text { by } 10 \text { points }\end{array}$ & $\begin{array}{l}\text { no liberal- } \\
\text { ization }\end{array}$ & \\
\hline & \multicolumn{2}{|c|}{$\begin{array}{l}\text { If }>30 \% \text { in top tier, } 2 \text { percentage } \\
\text { points more }\end{array}$} & & & & \\
\hline $\begin{array}{l}\text { Special } \\
\text { products }\end{array}$ & & $\begin{array}{l}14 \% \text { of lines; } 40 \% \\
\text { no cut and } 60 \% \\
\text { with } 15 \% \text { cut }\end{array}$ & $\begin{array}{l}\text { no liberal- } \\
\text { ization }\end{array}$ & & $\begin{array}{l}\text { no liberal- } \\
\text { ization }\end{array}$ & \\
\hline $\begin{array}{l}\text { Tariff } \\
\text { escalation } \\
\text { products }\end{array}$ & $\begin{array}{l}\text { Cut from next } \\
\text { higher tier } \\
\text { applied. In top } \\
\text { tier add } 6 \text { per- } \\
\text { centage points } \\
\text { to the cut }\end{array}$ & & $\begin{array}{l}\text { no liberal- } \\
\text { ization }\end{array}$ & & $\begin{array}{l}\text { no liberal- } \\
\text { ization }\end{array}$ & \\
\hline $\begin{array}{l}\text { Tropical } \\
\text { products }\end{array}$ & $\begin{array}{l}t \leq 10, \text { cut to zero; } \\
10<t \leq 75,70 \% \\
\text { cut; } t>75,78 \%\end{array}$ & & $\begin{array}{l}\text { no liberal- } \\
\text { ization }\end{array}$ & & $\begin{array}{l}\text { no liberal- } \\
\text { ization }\end{array}$ & \\
\hline Cotton & $\begin{array}{l}\text { Duty-free access } \\
\text { those developing } \\
\text { so to LDCs }\end{array}$ & $\begin{array}{l}\text { by developed and } \\
\text { countries able to do }\end{array}$ & $\begin{array}{l}\text { no liberal- } \\
\text { ization }\end{array}$ & & $\begin{array}{l}\text { no liberal- } \\
\text { ization }\end{array}$ & \\
\hline
\end{tabular}

Source: Laborde and Martin (2011a).

Note: Republic of Korea is treated as a developing country for agriculture. Economies treated as SVEs were: Antigua and Barbuda, Barbados, Belize, Bolivia, Botswana, Brunei Darussalam, Cameroon, Democratic Republic of the Congo, Côte d'Ivoire, Cuba, Dominica, Dominican Republic, Ecuador, El Salvador, Fiji, Gabon, Georgia, Ghana, Grenada, Guatemala, Guyana, Honduras, Jamaica, Jordan, Kenya, Macau, Mauritius, Mongolia, Namibia, Nicaragua, Nigeria, Panama, Papua New Guinea, Paraguay, Saint Kitts and Nevis, Saint Lucia, Saint Vincent and the Grenadines, Sri Lanka, Trinidad and Tobago, Uruguay, and Zimbabwe. RAMs treatment includes China, Croatia, Ecuador, Jordan, Mongolia, Oman, Panama, and Taiwan, China. VRAM treatment (no cuts) include Albania, Armenia, Georgia, Kyrgyz Republic, Republic of Moldova, the former Yugoslav Republic of Macedonia, Saudi Arabia, Tonga, Ukraine, and Viet Nam. The "special" product percentages are higher than in the December 2008 modalities because of the "serious objections" of some developing countries. 
TABLE 4.3 Average applied tariffs levied on World Trade Organization (WT0) agricultural products by scenario (\%)

\begin{tabular}{lrrrr}
\hline & \multicolumn{4}{c}{ Scenario } \\
\cline { 2 - 5 } Country or region & Baseline & \multicolumn{1}{c}{ B } & \multicolumn{1}{c}{ C } & \multicolumn{1}{c}{ D } \\
\hline Brazil & 4.8 & 4.7 & 4.7 & 4.8 \\
China & 7.8 & 5.3 & 6.3 & 7.5 \\
EU27 & 15.9 & 6.6 & 6.6 & 10.2 \\
India & 59.2 & 54.6 & 54.6 & 59.2 \\
Japan & 29.8 & 14.0 & 14.0 & 20.4 \\
United States & 4.8 & 2.1 & 2.1 & 3.0 \\
World Bank classification & & & & \\
All countries & 14.6 & 9.0 & 9.2 & 11.9 \\
Developing countries (non-LDCs) & 13.3 & 11.3 & 11.7 & 13.2 \\
High-income countries & 15.5 & 7.5 & 7.6 & 11.1 \\
Least developed countries (LDCs) & 12.5 & 12.2 & 12.5 & 12.5 \\
WT0 Classification & & & & \\
Developed WT0 & 15.4 & 7.0 & 7.0 & 10.4 \\
Developing WT0 (non-LDCs) & 13.7 & 11.2 & 11.6 & 13.6 \\
$\quad$ Normal developing WT0 & 15.1 & 12.3 & 12.3 & 15.0 \\
Recently acceded member (RAM) WT0 & 13.4 & 12.8 & 13.0 & 13.4 \\
Small and vulnerable economies (SVE) WT0 & 10.7 & 7.8 & 9.5 & 10.5 \\
\hline
\end{tabular}

Source: Laborde and Martin (2011a).

because of key features of the formula-the smaller cuts and higher-tier boundaries laid out in Table 4.1-and the greater binding overhang in many developing countries. Indeed, the cut on bound tariffs is about 61 percent for high-income countries and 38 percent for low- and middle-income countries, while applied tariffs are reduced by 52 and 15 percent respectively.

Without exceptions, the cut in the EU27 applied agricultural tariff is from 15.9 to 6.6 percent-a cut of almost 60 percent of its initial value. In the United States the corresponding cut is from 4.8 to 2.1 percent-a reduction of 56 percent from its initial value. The cut in Japan's average applied agricultural tariff is almost 16 percentage points, from 29.8 percent to 14 percenta reduction of over 50 percent. In Canada the cut would be from 10.7 to 5.1 percent, a reduction of more than 53 percent. The flexibilities for commodities-sensitive and special products-included in Scenario D more than halve the worldwide cut in tariffs, from 5.4 percent with only country flexibilities to 2.7 percent with country and commodity flexibilities. Interestingly, 
it is in the industrial countries that the cut in applied tariffs is reduced the most - with the tariff after flexibilities declining from 7.4 percentage points to 5 percentage points. In low- and middle-income (non-LDC) countries, these flexibilities reduce the cut from 1.6 percentage points to 0.1 percentage points - a larger proportional reduction than for high-income countries but a smaller one in percentage point terms.

\section{Nonagricultural Market Access Proposals}

The central feature of the modalities for nonagricultural market access (NAMA) is the use of a nonlinear tariff-cutting formula. The formula is applied on base rates equal to existing bound tariffs or average applied most favored nation (MFN) rates (period 1999-2001) plus 25 percent for currently unbound tariff lines. The tariff formula in this case is the highly nonlinear Swiss formula, which reduces the highest tariffs by the most. The Swiss formula requires tariffs in ad valorem terms, and all tariffs are to be converted into ad valorem terms and bound in those terms.

The Swiss formula is defined as:

$$
\mathrm{t}_{1}=\frac{a_{i} t_{0}}{a_{i}+t_{0}}
$$

where $t_{1}$ is the tariff after application of the formula; $t_{0}$ is the tariff rate before application of the formula; and $a_{i}$ is a coefficient for group $i$, which differs between developed and developing countries, and in line with the decisions of each developing country about the number of products it would like to subject to smaller tariff cuts.

The operation of the formula is perhaps most easily seen graphically, as in Figure 4.2, where the upper line shows the tariff after a formula with a coefficient of 20 percent, while the lower line shows the results of the formula with a coefficient of 8 percent. As is clear, the Swiss formula cuts the highest tariffs by the most, with tariffs of 100 percent being cut to 16.7 percent when using the coefficient of 20 percent and to 7.4 percent with a coefficient of 8 percent. In contrast, tariffs of 1 percent are barely cut in either case. Since the highest tariffs generate the largest economic costs, the Swiss formula is highly desirable from an economic efficiency view point. Politically, it is much more challenging, because it involves cutting high tariffs on products for which policy makers receive strong support for protection (Jean, Laborde, and Martin 2011). When it was used in the Tokyo Round of the GATT (1974-1979), it proved difficult to avoid substantial numbers of exceptions (Baldwin 1986), 
FIGURE 4.2 The Swiss formula for tariff cutting (\%)

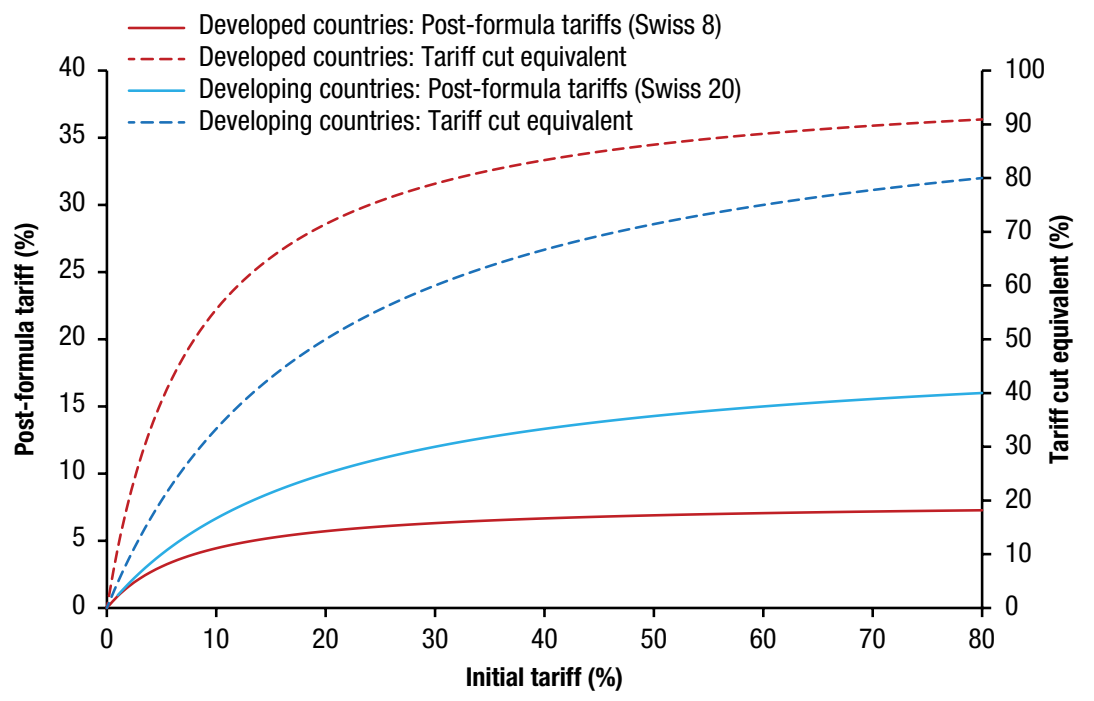

Source: Authors.

a problem that has recurred for developing countries in the Doha negotiations (Falconer 2008; Schwab 2011), although the industrial countries have been willing to consider its use without exceptions. The modalities provide for a single value of $a_{i}$ of 8 percent for industrial countries and three different choices for developing countries: 20 percent, 22 percent, or 25 percent. With a coefficient of 25 , no flexibilities would be available. Choosing lower coefficients allows members more access to flexibilities, as specified in Table 4.4.

Although the formula was originally intended to apply to all developing countries, many exceptions were made with the result that only around 20 developing countries would actually apply the formula. Details of these exceptions-which applied to SVEs, LDCs, and countries with less than 35 percent binding coverage (so-called Para 6 countries) — are given in Laborde and Martin (2011b), together with a discussion of the impact of the tariff cuts being implemented for bound rates given the frequent, large gaps between bound and applied tariffs. Where the modalities offered a choice of approaches, we followed the approach of Jean, Laborde, and Martin $(2011,2014)$ by using a political welfare function: identifying a policy maker's objective function to identify the option that would minimize the loss of policy makers' welfare. The political welfare function was also used to allocate the 22 developing countries undertaking NAMA tariff reductions with the Swiss formula to the 
TABLE 4.4 Tariff-cutting formula menu for the NAMA negotiations

\begin{tabular}{|c|c|c|c|c|}
\hline $\begin{array}{l}\text { Elements of } \\
\text { negotiation }\end{array}$ & $\begin{array}{l}\text { Developed } \\
\text { countries }\end{array}$ & Developing countries & $\begin{array}{l}\text { Least } \\
\text { developed } \\
\text { countries } \\
\text { (LDCs) }\end{array}$ & $\begin{array}{l}\text { Paragraph } 6 \\
\text { countries }\end{array}$ \\
\hline $\begin{array}{l}\text { Formula } \\
\text { Flexibility }\end{array}$ & $\begin{array}{l}\text { Swiss } 8 \\
\text { None }\end{array}$ & $\begin{array}{l}20 \text { (i): No cuts on } 6.5 \% / 7.5 \% \text { of lines/imports; } \\
20 \text { (ii): } 1 / 2 \text { cuts on } 14 \% / 16 \% \text { of lines/imports; } 22 \\
\text { (i): No cuts on } 5 \% / 5 \% \text { of lines/imports; } 22 \text { (ii) } \\
1 / 2 \text { cuts on } 10 \% / 10 \% \text { of lines/imports; } 25 \text { : No } \\
\text { flexibilities }\end{array}$ & $\begin{array}{l}\text { No } \\
\text { liberalization }\end{array}$ & $\begin{array}{l}\text { No } \\
\text { liberalization }\end{array}$ \\
\hline Unbound & \multicolumn{4}{|c|}{ Most favored nations (MFN) $2001+25 \%$} \\
\hline
\end{tabular}

Source: Laborde and Martin (2011b).

Note: NAMA = nonagricultural market access. Members self-selected developing- or developed-country status. Members likely selecting developed-country status include members of the European Union, plus Australia, Canada, Iceland, New Zealand, Norway, Switzerland, and the United States. The Republic of Korea is a developed country for NAMA. LDCs are identified in the UN list of least developed countries. Economies treated as SVEs for NAMA were Antigua and Barbuda, Barbados, Belize, Bolivia, Botswana, Brunei Darussalam, Cameroon, Cuba, Dominica, Dominican Republic, Ecuador, El Salvador, Fiji, Gabon, Georgia, Ghana, Grenada, Guatemala, Guyana, Honduras, Jamaica, Jordan, Kenya, Macau, Mauritius, Mongolia, Namibia, Nicaragua, Panama, Papua New Guinea, Paraguay, Saint Kitts and Nevis, Saint Lucia, Saint Vincent and the Grenadines, Sri Lanka, Trinidad and Tobago, Uruguay, and Zimbabwe. Paragraph 6 economies (those with less than 35 percent of tariffs bound) were identified as Cameroon, China, Democratic Republic of the Congo, Cuba, Ghana, Kenya, Macau, Mauritius, Nigeria, Sri Lanka, Suriname, and Zimbabwe. The following VRAMs are not required to make any tariff cuts beyond their accession commitments: Albania, Armenia, Cape Verde, Kyrgyz Republic, the former Yugoslav Republic of Macedonia, Republic of Moldova, Mongolia, Saudi Arabia, Tonga, Viet Nam, and Ukraine.

option that minimized the political cost of NAMA tariff cuts. A summary of the way the tariff-cutting menu was implemented is given in Table 4.4.

The tariff scenarios reported are:

- Baseline: Tariffs that would apply in the absence of a DDA agreement in 2025. These are based on tariffs in 2004 , with adjustments for internationally binding commitments to reform.

- B: Tariffs following implementation of the DDA formula without flexibilities.

- C: Tariffs following implementation of the formula with country exceptions, such as those for LDCs, SVEs, and RAMs.

- D: Tariffs after the tariff-cutting formulas with flexibilities for countries and products.

The tariff-cutting formulas are applied to bound tariffs rather than to applied tariffs, and hence it is useful to first examine the implications of the formula and exceptions for the level of bound tariffs. We use the standard assumption in this literature that the applied rate at the finest available level is cut only when, and to the extent that, the new bound tariff falls below the initial applied tariff rate. 
TABLE 4.5 Average (trade-weighted) applied tariffs levied on World Trade Organization (WTO) nonagricultural products by scenario (\%)

\begin{tabular}{lcccc}
\hline & \multicolumn{4}{c}{ Scenario } \\
\cline { 2 - 5 } Country or region & Baseline & \multicolumn{1}{c}{ B } & \multicolumn{1}{c}{ C } & \multicolumn{1}{c}{ D } \\
\hline Brazil & 5.5 & 7.4 & 7.4 & 7.8 \\
China & 1.8 & 1.0 & 1.0 & 1.0 \\
EU27 & 12.9 & 11.7 & 11.7 & 12.0 \\
India & 1.3 & 0.7 & 0.7 & 0.7 \\
Japan & 1.5 & 0.8 & 0.8 & 0.8 \\
United States & & & & \\
World Bank Classification & 2.9 & 2.0 & 2.2 & 2.3 \\
All countries & 6.1 & 4.6 & 5.0 & 5.3 \\
Low- and middle-income countries & 1.6 & 1.0 & 1.0 & 1.0 \\
High-income countries & 10.9 & 8.0 & 10.9 & 10.9 \\
Least developed countries (LDCs) & & & & \\
WT0 Classification & 1.7 & 1.0 & 1.0 & 1.0 \\
Developed WT0 & 4.8 & 3.6 & 3.8 & 4.2 \\
Developing WT0 non-LDCs & 3.9 & 3.1 & 3.1 & 3.4 \\
$\quad$ Normal Developing WTO & 9.5 & 7.1 & 9.5 & 9.5 \\
Recently acceded members (RAMs) WT0 & 5.3 & 3.9 & 4.0 & 4.4 \\
Small and vulnerable economies (SVEs) WT0 & 5 & & &
\end{tabular}

Source: Laborde and Martin (2011b).

Moving to the reductions in applied tariff rates in Table 4.5, we see that, if the formulas were applied without exceptions, average tariffs would fall from 2.9 percent to 2.0 percent. ${ }^{4}$ In the high-income countries, the reduction is from 1.6 percent to 1.0 percent, a reduction of 0.6 percentage points. Interestingly, the effect of the Swiss formula is strongly dampened by the existing trade and tariff structure: for developed economies, the average cut on bound tariffs will be below 50 percent due to the fact that 53 percent of their products-75 percent of their MFN imports-have tariffs of below 4 percent. In non-LDC low- and middle-income countries, the reduction is estimated to be from 6.1 percent to 4.6 percent: 2.5 percentage points, a cut of four-tenths of the original tariff. In some developing countries (such as Bangladesh, Pakistan, and Thailand), application of the formula alone would appear to result in

4 Under this no-flexibilities scenario, a coefficient of 25 is chosen for all developing countries. 
substantial cuts in average tariffs. ${ }^{5}$ When we consider the group of countries that would apply the standard developing-country formula, the reduction in tariffs is from 3.9 percent to 3.1 percent, a cut of 0.8 percentage points-a much smaller cut than would apply were this formula applied to the RAMs and SVEs. For low- and middle-income countries, the overall limited effect of the formula is driven by an average large binding overhang (an average reduction of 41 percent in bound tariffs translates to a 25 percent cut in applied tariffs).

\section{Why So Much Political Resistance?}

The formulas used in both the agricultural and nonagricultural negotiations were highly progressive, in terms of cutting the highest tariffs by the most. From an economic point of view, these are outstandingly good approaches to tariff reform, because the economic costs of a tariff rise with the square of the rate. But this economic virtue may have an associated downside. High tariffs are that way because there is strong political support for the beneficiaries of this high protection. If, as Falconer (2008) has suggested, the aggressive nature of these tariff-cutting formulas resulted in intense pressure for exceptions, excessive zeal in the tariff-cutting formulas may have contributed to the problems created by the exceptions-including the loss of market access liberalization, reduced efficiency of tariff cutting, and a lack of transparency about the implications of the reform.

\section{A Political Economy Framework for Trade Reform}

A fundamental challenge in choosing tariff-reduction formulas is a lack of clarity in the objectives of the formula. Trade theory provides little guidance on which specific forms to pick other than that progressive tariff cuts and proportional cuts are likely to result in Pareto improvements (Vousden 1990, Chapter 10) - but there is no guarantee that these will be politically acceptable. Anderson and Neary (2007) show that reducing multiple tariffs may lead to a "policy dilemma" since market access and welfare gains evolve differently when tariff dispersion is changed. They show that reforms that increase both welfare and market access may exist, but identifying them requires more information about the structure of the economy (for example, relative prices and cross-price effects) than is usually assumed.

In order to study the effects of the market access options proposed in the Doha Round, Jean, Laborde, and Martin (2011) used a political economy

5 In this scenario no duty-free quota-free (DFQF) initiative for LDCs is considered. 
framework inspired by Grossman and Helpman (1994). The resulting political welfare function in (1) takes into account the political benefits resulting from a set of domestic prices and the economic costs of the trade barriers needed to sustain those prices.

$$
G(\mathbf{p}, u)=\frac{1}{a} i \mathbf{C}(\mathbf{p})+\left(-z(\mathbf{p}, u)+\mathbf{z}_{\mathbf{p}}^{\prime}\left(\mathbf{p}-\mathbf{p}^{*}\right)\right)
$$

where $\mathrm{C}(\mathrm{p})$ is the vector of benefits accruing to politicians at domestic prices, $\mathbf{p} ; l$ is a vector of ones; $\boldsymbol{a}$ is the weight that politicians place on aggregate welfare relative to political support provided to them, $z(\mathbf{p}, u)=\mathrm{e}(\mathbf{p}, \mathrm{u})-\mathrm{g}(\mathbf{p})$ is the balance of trade measure of economic welfare, defined as the difference between the expenditure function $e(\mathbf{p}, \mathrm{u})$ for utility level of the representative household, $\mathrm{u}$, and a net revenue function defined to include revenue from production $\mathrm{g}(\mathrm{p})$, and tariff revenues, $\mathbf{z}_{\mathrm{p}}\left(\mathbf{p}-\mathbf{p}^{*}\right)$; where $\mathbf{p}$ is a vector of domestic prices; $\mathbf{p}^{*}$ is the vector of world prices; so that $\left(\mathbf{p}-\mathbf{p}^{*}\right)$ is a vector of specific tariff rates. $\mathbf{z}_{\mathrm{p}}=\mathbf{e}_{\mathrm{p}}-\mathbf{g}_{\mathrm{p}}$ is a vector of net imports, and $\mathbf{z}_{\mathrm{p}}{ }^{\prime}\left(\mathbf{p}-\mathbf{p}^{*}\right)$ is tariff revenues, which are assumed to be redistributed to households. ${ }^{6}$

Assuming that the initial situation reflects a political-economy optimum, the initial tariff structure can be used to characterize the column sums of $\mathbf{C}$, which are the perceived net impacts of changes in the price of one product on political support. Writing these column sums divided by $a$ as a row vector $\mathbf{h}$, and setting $\frac{d G}{d p}=0$, yields a potentially observable expression for $\mathbf{h}$ at the initial domestic price vector. The resulting equation reveals politicians' preferences at the margin by equating the marginal political benefits to politicians of providing protection with the marginal economic costs they are willing to incur in order to provide this support:

$$
\mathbf{h}=-\left(\mathbf{p}^{0}-\mathbf{p}^{*}\right)^{\prime} \mathbf{z}^{0}{ }_{\mathrm{pP}}
$$

Here, we focus on the short-run case where the political influence of a given sector (or product) is assumed to be constant over the relevant political cycle.

Figure 4.3 considers the case of a single tariff. The marginal political benefits, 1/a . MC, rise with the level of the tariff, but less rapidly than the social costs, or the protection rate would be infinite. The short-run contribution function is represented by the line h because, as shown by Hillman (1982), short-run political support from firms is likely related to current output rather than the output after adjustment to a price change.

6 Throughout, bold characters refer to vectors or matrices while lower case characters refer to scalars. 
FIGURE 4.3 Marginal political benefits and economic costs of a tariff

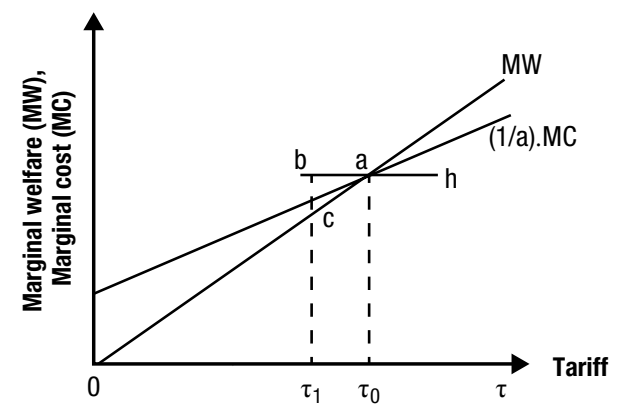

Source: Authors.

This analytical framework extended by Jean, Laborde, and Martin (2014) allows us to define the trade-off in terms of the political cost, welfare, and market access impacts of any trade policy reform. It also provides some potentially very helpful guidelines for reform in the particular case where crossprice effects in the demand matrix can be ignored, demand curves are linear, and small tariff changes are considered. For example, under these specific assumptions, it shows that a benevolent policy maker attempting to maximize the efficiency gains per unit of political cost will choose a proportional cut in all applied tariffs. In contrast, a negotiator seeking to minimize the political cost of achieving a given level of market access expansion will tend to reduce all ad valorem tariffs by a constant absolute amount. Finally, a social planner seeking to maximize the change in the economic efficiency to market access ratio will move toward a uniform tariff.

Even if these rules assume specific restrictions on the demand system, and assume that tariff-cutting formulas are imposed on applied tariffs, rather than bound tariffs, they provide essential insights. The traditional recommendation of the literature about harmonizing formulas aimed to reduce tariff heterogeneity and increase the efficiency of any trade reform no longer appears to be a first best choice when political constraints are considered. Indeed, the political cost of an aggressive formula may exhaust the political capital available during trade talks quickly, reducing strongly the capacity of the negotiation cycle to deliver large market access or welfare gains. At the opposite end, softer formulae such as proportional cuts may be a better compromise, where political capital is limited, to deliver either market access or welfare.

The problem of high political costs with the initially considered formula approach might be addressed by changing the formula or by considering 
alternative formulas. The second approach was floated by Falconer (2008), who suggested moving from the tiered-formula approach to an average-cut approach. A difficulty with this approach is that it might have prejudiced the negotiations by putting at risk their market access goal. Members who were free to choose their tariff cuts-even if subject to minimal constraints, such as a minimum cut in each tariff line-might use the smallest cuts on products that had high import-demand elasticities, high initial import volumes, or both in such a way that the market access opportunities created would not generate sufficient interest for the negotiations to proceed.

However, if discretionary exceptions to tariff-cutting formulas are to be allowed-as they have been in the Doha proposals - the design of these exceptions is important and should take into account political-economy considerations as well as the implications of the proposed exceptions for the market access of partner countries. The product exceptions allowed in the Doha proposals for agriculture involved only limits on the number of tariff lines, a totally inadequate discipline. As shown by Jean, Laborde, and Martin (2011), this approach allows members to apply small cuts to products that are important and for which large cuts in applied tariff rates would be required by the formula. As we have seen, this resulted in the cuts in applied tariffs being reduced dramatically relative to the formula cuts-particularly in highincome countries. As they showed, moving to disciplines on the share of trade covered would have sharply reduced the adverse consequences of exceptions for the negotiations. Constraining the impact of flexibilities by limiting the trade volume on which they could be applied was shown by Jean, Laborde, and Martin (2011) to be very helpful in reducing their adverse impacts on market access. Perhaps a better-but still potentially feasible—approach would be to constrain the use of flexibilities: the greater the flexibilities' impact, as measured on a mercantilist trade restrictiveness index of the type proposed by Anderson and Neary (2003), the greater the constraints on their use. Alternatively, a cost for flexibilities might be incorporated by requiring countries to negotiate exceptions from the general tariff formula via requestand-offer negotiations.

\section{What Might Make an Agreement Feasible?}

Using the AMA proposals and the Jean, Laborde, and Martin (2011, 2014) framework, we examine the implications of the formula relative to welfare and market gains versus political costs. For this analysis we assume that consumer preferences can be represented using a CES function covering all goods, and that policy makers ignore any impacts of their tariff changes on world prices. 
Table 4.6 displays for all WTO members as a group, and for selected countries, the expected effects of the formula (Scenario $\mathrm{C}$ in Table 4.3), and of the formula plus flexibilities (Scenario D in Table 4.3) relative to a proportional cut in bound tariffs leading to the same market access outcomes. All relevant variables for policy makers (welfare gains, market access concessions-that is, import increases-and political costs) are expressed as a percentage of the Scenario C effects (the strongest market opening, before introducing product flexibilities). We characterize each scenario using the ratios that characterize different policy makers: efficiency gain per unit of political cost for the benevolent policy maker, welfare gain per unit of market access for the social planner, and political cost per unit of market access for the negotiator. Market access changes are measured in terms of changes in imports. At the global level the overall market access also represents the overall improvement in market access for all exporters.

The results in Table 4.6 provide a number of insights. Looking at the criterion of welfare and efficiency gains per unit of market access granted, we generally find declines as we move from the tiered formula (C) to a proportional cut $(\mathrm{C} 1)$. This is consistent with the economically high-quality nature of the tiered formula, which imposes larger cuts on the higher tariffs. Now, focusing on the criterion of the benevolent policy maker, the welfare gains per unit of political cost incurred rise when we move from the formula cuts to a proportional cut with the same level of market access. In the all-members case, the increase is from 1.59 to 1.63 . For individual countries, the increases are generally in the same order of magnitude. The political costs per unit of import access provided also decline as we move to the proportional formula. While these results are consistent with the Jean, Laborde, and Martin (2014) finding that proportional cuts are optimal for a benevolent policy maker, they cannot be taken for granted since both the formula and the proportional cut are applied to bound tariffs, and this analysis takes into account cross-price effects in the demand system. The proportional cut approach lowers the political cost per unit of market access given - the criterion of the pure negotiatorin all cases.

Overall, the flexibilities (Scenario C to Scenario D) cut by half the magnitude of the welfare and market access gains at the global level. When we turn to Formula Scenario D, with product flexibilities, we find that the efficiency of the reform per unit of market access is reduced: increased flexibilities reduce welfare gains more rapidly than market access due to the increase in tariff heterogeneity. Looking at the political economy of the reform, a more complex situation arises. The political costs per unit of market access provided 
TABLE 4.6 Welfare, market access, and political costs of formulae and flexibilities: AMA

\begin{tabular}{|c|c|c|c|}
\hline & $\begin{array}{l}\text { Efficiency gains per } \\
\text { unit of additional } \\
\text { imports (\%) }\end{array}$ & $\begin{array}{c}\text { Efficiency gains } \\
\text { per unit of political } \\
\text { cost (\%) }\end{array}$ & $\begin{array}{l}\text { Political cost per } \\
\text { unit of additional } \\
\text { imports (\%) }\end{array}$ \\
\hline \multicolumn{4}{|c|}{ Total WTO members with effective market access concessions } \\
\hline Formula Scenario C & 0.84 & 1.59 & 0.53 \\
\hline Proportional cut equivalent to $\mathrm{C} 1$ & 0.80 & 1.63 & 0.49 \\
\hline Formula and Flexibilities Scenario D & 0.77 & 1.63 & 0.48 \\
\hline Proportional cut equivalent to D1 & 0.80 & 1.53 & 0.52 \\
\hline \multicolumn{4}{|l|}{ Brazil } \\
\hline Formula Scenario C & 0.58 & 3.52 & 0.16 \\
\hline Proportional cut equivalent to $\mathrm{C} 1$ & 0.58 & 3.68 & 0.16 \\
\hline \multicolumn{4}{|l|}{ China } \\
\hline Formula Scenario C & 0.62 & 2.61 & 0.24 \\
\hline Proportional cut equivalent to $\mathrm{C} 1$ & 0.60 & 2.97 & 0.20 \\
\hline Formula and Flexibilities Scenario D & 0.59 & 3.32 & 0.18 \\
\hline Proportional cut equivalent to D1 & 0.61 & 2.85 & 0.21 \\
\hline \multicolumn{4}{|l|}{ European Union } \\
\hline Formula Scenario C & 0.79 & 1.70 & 0.47 \\
\hline Proportional cut equivalent to $\mathrm{C} 1$ & 0.78 & 1.72 & 0.45 \\
\hline Formula and Flexibilities Scenario D & 0.80 & 1.54 & 0.52 \\
\hline Proportional cut equivalent to D1 & 0.82 & 1.47 & 0.56 \\
\hline \multicolumn{4}{|l|}{ India } \\
\hline Formula Scenario C & 0.81 & 1.43 & 0.57 \\
\hline Proportional cut equivalent to $\mathrm{C} 1$ & 0.80 & 1.47 & 0.54 \\
\hline Formula and Flexibilities Scenario D & 0.67 & 2.04 & 0.33 \\
\hline Proportional cut equivalent to D1 & 0.85 & 1.25 & 0.68 \\
\hline \multicolumn{4}{|l|}{ Japan } \\
\hline Formula Scenario C & 0.81 & 1.64 & 0.49 \\
\hline Proportional cut equivalent to $\mathrm{C} 1$ & 0.75 & 1.69 & 0.44 \\
\hline Formula and Flexibilities Scenario D & 0.74 & 1.68 & 0.44 \\
\hline Proportional cut equivalent to D1 & 0.74 & 1.64 & 0.45 \\
\hline \multicolumn{4}{|l|}{ United States } \\
\hline Formula Scenario C & 0.61 & 2.61 & 0.24 \\
\hline Proportional cut equivalent to $\mathrm{C} 1$ & 0.61 & 2.71 & 0.22 \\
\hline Formula and Flexibilities Scenario D & 0.62 & 2.55 & 0.24 \\
\hline Proportional cut equivalent to D1 & 0.62 & 2.55 & 0.24 \\
\hline
\end{tabular}

Source: Authors' computation.

Note: The Flexibilities Scenario reduces effective agricultural trade liberalization in Brazil to nearly $0 . A M A=$ agricultural market access. 
to trading partners-the sine qua non of political success-is unchanged for WTO members as a whole. The flexibilities reduce the overall political cost in the same proportion as the market access gains. However, for WTO members such as India, the political costs per unit of trade expansion fall sharply. For all the other members represented in Table 4.6, however, the political costs per unit of market access rise, substantially in the case of the European Union. The welfare gains per unit of political cost decline slightly for WTO members as a whole, while rising substantially for India. This outcome would not arise in the textbook case where tariff cuts are imposed on applied rates and cross-price effects are absent. It arises because of the complex relationship between the applied and bound tariff schedules and the selective nature of the flexibilities. In the final row of each block, we move from Scenario D to a proportional cut that yields the same market access outcome. In each case except the United States, this increases the political costs per unit of market access, reducing the scope for agreement among negotiators focused on mercantilist goals. It does, however, increase the economic welfare gains per unit of political cost expended.

When we turn to NAMA in Table 4.7, we find results that are broadly similar for WTO members as a group. As we move from the Swiss formula to the proportional cut, the political costs of concern to the negotiator fall quite sharply, and the welfare gains per unit of political cost rise, even though the welfare gains per unit of market access fall as we move away from the Swiss formula. The political costs per unit of market access fall further as exceptions are introduced. In this case, however, these political costs are the same when a proportional cut calibrated to the market access gains of the formula plus flexibilities is introduced.

For each of the industrial countries considered, the political cost per unit of market access falls quite sharply as we move from the tiered formula to a proportional cut, while the efficiency gains per unit of political cost rise. This reflects both the sharp reduction in political costs incurred and the increase in market access as goods that are both high volume and relatively low tariff face larger tariff cuts. The picture is more complex in developing countries, where flexibilities are allowed. In Brazil the political cost per unit of market access rises as the flexibilities are introduced, and the efficiency gains per unit of political cost fall. In contrast, in India and China the formula with flexibilities minimizes the political costs per unit of market access provided and maximizes the efficiency gains per unit of political cost.

A key feature of the current impasse is the fact that the combination of initial low tariffs in developed economies, high binding overhang in developing 
TABLE 4.7 Welfare, market access, and political costs: NAMA

\begin{tabular}{|c|c|c|c|}
\hline & $\begin{array}{l}\text { Welfare per } \\
\text { unit of political } \\
\text { cost }(\%)\end{array}$ & $\begin{array}{c}\text { Welfare } \\
\text { per unit } \\
\text { of market } \\
\text { access (\%) }\end{array}$ & $\begin{array}{l}\text { Political cost } \\
\text { per unit of } \\
\text { additional } \\
\text { imports }(\%)\end{array}$ \\
\hline \multicolumn{4}{|l|}{ All WTO countries } \\
\hline Formula without Flexibilities (Scenario C) & 4.17 & 0.63 & 0.15 \\
\hline Proportional cut (calibrated market access on Scenario C) & 4.94 & 0.61 & 0.12 \\
\hline Formula with Flexibilities (Scenario D) & 5.41 & 0.60 & 0.11 \\
\hline Proportional cut (calibrated market access on Scenario D) & 5.48 & 0.60 & 0.11 \\
\hline \multicolumn{4}{|l|}{ All WTO countries with effective opening } \\
\hline Formula without Flexibilities (Scenario C) & 4.18 & 0.63 & 0.15 \\
\hline Proportional cut (calibrated market access on Scenario C) & 4.94 & 0.61 & 0.12 \\
\hline Formula with Flexibilities (Scenario D) & 5.42 & 0.60 & 0.11 \\
\hline Proportional cut (calibrated market access on Scenario D) & 5.48 & 0.60 & 0.11 \\
\hline \multicolumn{4}{|l|}{ Brazil } \\
\hline Formula without Flexibilities (Scenario C) & 3.71 & 0.63 & 0.17 \\
\hline Proportional cut (calibrated Market Access on Scenario C) & 3.87 & 0.63 & 0.16 \\
\hline Formula with Flexibilities (Scenario D) & 3.77 & 0.63 & 0.17 \\
\hline Proportional cut (calibrated market access on Scenario D) & 3.79 & 0.63 & 0.17 \\
\hline \multicolumn{4}{|l|}{ China } \\
\hline Formula without Flexibilities (Scenario C) & 3.77 & 0.66 & 0.17 \\
\hline Proportional cut (calibrated market access on Scenario C) & 5.05 & 0.62 & 0.12 \\
\hline Formula with Flexibilities (Scenario D) & 5.93 & 0.61 & 0.10 \\
\hline Proportional cut (calibrated market access on Scenario D) & 5.00 & 0.62 & 0.12 \\
\hline \multicolumn{4}{|l|}{ European Union } \\
\hline Formula without Flexibilities (Scenario C) & 8.21 & 0.57 & 0.07 \\
\hline Proportional cut (calibrated market access on Scenario C) & 9.39 & 0.56 & 0.06 \\
\hline \multicolumn{4}{|l|}{ India } \\
\hline Formula without Flexibilities (Scenario C) & 2.38 & 0.73 & 0.31 \\
\hline Proportional cut (calibrated market access on Scenario C) & 2.63 & 0.70 & 0.27 \\
\hline Formula with Flexibilities (Scenario D) & 4.18 & 0.64 & 0.15 \\
\hline Proportional cut (calibrated market access on Scenario D) & 2.46 & 0.72 & $\begin{array}{l}0.29 \\
\text { (continued) }\end{array}$ \\
\hline
\end{tabular}




\begin{tabular}{lccc}
\hline & $\begin{array}{c}\text { Welfare per } \\
\text { unit of political } \\
\text { cost (\%) }\end{array}$ & $\begin{array}{c}\text { Welfare } \\
\text { per unit } \\
\text { of market } \\
\text { access (\%) }\end{array}$ & $\begin{array}{c}\text { Political cost } \\
\text { per unit of } \\
\text { additional } \\
\text { imports (\%) }\end{array}$ \\
\hline Japan & 4.98 & 0.59 & 0.12 \\
Formula without Flexibilities (Scenario C) & 5.94 & 0.58 & 0.10 \\
Proportional cut (calibrated market access on Scenario C) & & & \\
United States & 6.72 & 0.59 & 0.09 \\
Formula without Flexibilities (Scenario C) & 8.76 & 0.58 & 0.07 \\
Proportional cut (calibrated market access on Scenario C) & & &
\end{tabular}

Source: Authors' computations.

Note: NAMA = nonagricultural market access. The industrial countries are allowed no flexibilities.

economies, and flexibilities have led to limited gains in the nonagricultural sector. With limited possibilities for gain in the manufacturing sectors, the fuel that drove previous rounds of negotiation is running perilously close to dry, as noted in Martin and Messerlin (2007). This makes it difficult for policy makers in developed economies to engage the export interests whose support, and even enthusiasm, was critical in reaching earlier multilateral agreements. Without engaging these interest groups, it is difficult for policy makers to find a solution to counterbalance the pressure from agricultural interests to retain their protection.

Beyond solving the basic domestic political-economy equation, the Doha Round embodies a paradigm shift in global trade negotiations and their governance. Agreement between the EU and the United States is no longer sufficient for a global agreement. Emerging countries_-in particular Brazil, China, and India-have become key players in terms of commercial and diplomatic strength. Obviously, increasing the number of players increases the difficulty of finding a positive outcome to the bargaining game (Bouët and Laborde 2010). It has also resulted in concerns about the traditional GATT practice of treating all developing countries other than the LDCs in the same way in terms of special and differential treatment.

Although initially less protected than agriculture, due to its size and role in world trade of goods and services ( 91 percent of trade in goods, 78 percent of all trade in 2010), any concessions on NAMA could potentially have largescale effects. In this context the sectoral initiatives (that is, developing countries engaging in tariff elimination or tariff capping at a very low level for a 
subset of products, negotiated on a plurilateral basis and at the industry level) appear to be a potentially important complement to the formula approach. Laborde (2011) proposes an extensive discussion and quantification of these initiatives. They appear as another circumvention of a rigid harmonizing formula approach, in order to push the scope of liberalization while still respecting the political constraints and incentives of policy makers.

Indeed, the Swiss formula approach proposed in the modalities and discussed earlier fails to deliver significant market access gains for two reasons: for developed countries, the Swiss formula with a coefficient of 8 performs poorly on market access because many products with large trade volumes are subject to relatively low tariffs. With 53 percent of HS-6 products, and more than 75 percent of MFN imports of these countries, being subject to tariffs of 4 percent or lower, the cuts in average tariffs are modest. For developing countries, higher binding overhang and the inclusion of flexibilities to address their political constraints water down the liberalization. At the same time, aggressiveness of the Swiss formula leads to high political costs, in particular for tariff peaks (see Table 4.7 and its discussion). In contrast, the sectoral initiatives could deliver large and effective cuts to applied rates-and hence increases in market access - of value to almost all members in the very short run (Laborde 2011). The seven main initiatives (that is, those supported by countries who account for more than one-third of NAMA imports) would increase overall market access concessions in NAMA by one-third and eliminate the asymmetry among WTO members in terms of concessions and gains.

\section{Conclusion}

The Doha proposals involve tariff formulas that cut high tariffs much more sharply than lower tariffs. From an economic point of view, this is highly desirable and has potential to yield Pareto improvements (Turunen-Red and Woodland 1991; Vousden 1990). However, it is far from clear that this approach is politically achievable. As observed by one of the key negotiators (Falconer 2008), as soon as it was adopted, the pressure for flexibilities and exceptions became intense. Another key feature of the tariff-cut proposals is a wide range of exceptions. Many of these are extremely badly designed in allowing countries excessive flexibility to impose very small tariffs on products that are collectively important to exporters. In the agricultural agreement in particular, these flexibilities are constrained only by the number of products that can be included-a criterion that provides insufficient discipline 
since only a very small share of tariff lines account for most of the imports and trade restrictiveness.

A simple model based on the political-economy framework developed by Grossman and Helpman (1994) provides powerful insights into the political costs associated with movements from the political-economy equilibrium that underlies the initial tariff regime. Just as the economic costs of raising protection from its initial level are quadratic in the tariff, the political costs of lowering the tariff from its initial level are also quadratic. This suggests that attempts to use formulas that sharply reduce the highest tariffs are likely to incur political costs that put achieving international agreement at risk. A tariff formula that comes closer to reducing tariffs proportionally seems likely to provide a better balance between the political costs of reform and the desirability of achieving improvements in economic efficiency.

A detailed examination of the formulas proposed under the Doha Agenda shows that the political costs of an agreement to increase market access could have been reduced substantially by using a proportional-cut approach rather than progressive tariff-cutting formulas. Returning to a proportional-cut approach at the same level of market access concessions would generally raise the welfare gains per unit of political costs incurred. However, this approach is likely to be difficult because exceptions tend to lower the political costs associated with the level of market access provided. This suggests that the combination of ambitious formulas with deep exceptions customized to the specific situation of applied and bound tariffs frequently has more political appeal than might have been expected. While this approach compromises the economic efficiency goals of the negotiations, the results in this chapter suggest that it has probably not been the cause of the political stalemate that has becalmed the Doha negotiations.

\section{Bibliography}

Anderson, J., and P. Neary. 2003. "The Mercantilist Index of Trade Policy." International Economic Review 44 (2): 627-649.

- 2007. "Welfare versus Market Access: The Implications of Tariff Structure for Tariff Reform." Journal of International Economics 71: 187-205.

Baldwin, R. E. 1986. “Toward More Efficient Procedures for Multilateral Trade Negotiations.” Aussenwirtschaft 41 (Heft II/III): 379-394.

Baldwin, R., and G. Lage. 1971. "A Multilateral Model of Trade-Balancing Tariff Concessions." Review of Economics and Statistics 53: 237-245. 
Bouët, A., and D. Laborde. 2010. "Why Is the Doha Development Agenda Failing? And What Can Be Done? A Computable General Equilibrium-Game Theoretical Approach." The World Economy 33 (11): 1486-1516.

Falconer, C. 2008. "Communication from the Committee on Agriculture." Special Session, World Trade Organization (WTO), April 30. Accessed 2009. www.wto.org/english/tratop_e/ agric_e/chair_texts07_e.htm.

Francois, J., and W. Martin. 2003. "Formula Approaches for Market Access Negotiations." The World Economy 26 (1): 1-28.

_.2004. "Commercial Policy, Bindings, and Market Access." European Economic Review 48 (June): 665-679.

Grossman, G., and E. Helpman. 1994. "Protection for Sale." American Economic Review 84 (4): 833-850.

Hillman, A. 1982. "Declining Industries and Political-Support Protectionist Motives." American Economic Review 72 (5): 1180-1187.

Jean, S., D. Laborde, and W. Martin. 2011. "Formulas and Flexibility in Trade Negotiations: Sensitive Agricultural Products in the World Trade Organization's Doha Agenda." World Bank Economic Review 24 (3): 500-519.

_.2014. "The Political Costs of Policy Reform." Unpublished manuscript. World Bank, Washington, DC.

Laborde, D. 2011. “Sectoral Initiatives in the Doha Round.” In Unfinished Business? The WTO's Doha Development Agenda, edited by A. Mattoo and W. Martin, 277-298. London: Center for Economic Policy Research; Washington, DC: World Bank.

Laborde, D., and W. Martin. 2011a. "Agricultural Market Access." In Unfinished Business? The WTO's Doha Agenda, edited by A. Mattoo and W. Martin, 35-54. London: Center for Economic Policy Research; Washington, DC: World Bank.

_ 2011b. "Non-agricultural Market Access." In Unfinished Business? The WTO's Doha Agenda, edited by A. Mattoo and W. Martin, 55-68. London: Center for Economic Policy Research; Washington, DC: World Bank.

- 2015. "Formulas for Failure? Were the Doha Tariff Formulas Too Ambitious for Success?" World Trade Review 14 (1): 45-65.

Laborde, D., W. Martin, and D. van der Mensbrugghe. 2011. Measuring the Benefits of Global Liberalization with Optimal Aggregators of Trade Distortions. World Bank Policy Research Working Paper 5665. Washington, DC: World Bank.

Martin, W., and A. Mattoo. 2011. Unfinished Business: The WTO's Doha Agenda. London: CEPR; Washington, DC: World Bank. 
Martin, W., and P. Messerlin. 2007. "Why Is It So Difficult? Trade Liberalization under the Doha Agenda." Oxford Review of Economic Policy 23 (3): 347-366.

Schwab, S. 2011. "After Doha: Why the Negotiations Are Doomed and What We Should Do About It." Foreign Affairs 90 (3): 104-117.

Turunen-Red, A., and A. Woodland. 1991. "Strict Pareto-improving Multilateral Reforms of Tariffs." Econometrica 59 (4): 1127-1152.

Vousden, N. 1990. The Economics of Trade Protection. Cambridge, UK: Cambridge University Press.

WTO (World Trade Organization). 2008a. Revised Draft Modalities for Agriculture, TN/ AG/W/4/Rev.4, December 6. World Trade Organization, Geneva.

.2008b. Draft Modalities for Non-agricultural Market Access, TN/MA/W/103/Rev.3, December 6. World Trade Organization, Geneva. 